\title{
ENHANCING PROCUREMENT DECISIONS THROUGH EFFECTIVE LEADERSHIP: A CASE OF LIBYAN MINISTRY OF DEFENCE
}

\author{
DOI: 10.17261/Pressacademia.2018.942 \\ RJBM-V.5-ISS.3-2018(1)-p.184-190
}

\author{
Mohamad Hisyam Selamat ${ }^{1}$, Abdulrahman Sultan Elwahj ${ }^{2}$ \\ ${ }^{1}$ Faculty of Business, Accounting and Management, SEGi University, Petaling Jaya, Malaysia. \\ mohdhisyam@segi.edu.my, ORCID:0000-0003-4660-3520 \\ ${ }^{2}$ Institute of Graduate Studies, SEGi University, Petaling Jaya, Malaysia. \\ othman0872@yahoo.com, ORCID: 0000-0002-8384-4078
}

To cite this document

Selamat, M. H., Elwahj, A. S. (2018). Enhancing procurement decisions through effective leadership: a case of Libyan Ministry of Defence. Research Journal of Business and Management (RJBM), 5(3), p.184-190.

Permemant link to this document: http://doi.org/10.17261/Pressacademia.2018.942

Copyright: Published by PressAcademia and limited licenced re-use rights only.

\section{ABSTRACT}

Purpose- This study is designed to propose values for enhancing procurement decisions. The proposed values are leadership commitment and leadership communication.

Methodology- This research adopted quantitative research approach to analyze the data obtained from the questionnaire distributed to the employees in the Libyan Ministry of Defence. A total of 450 employees in the Libyan Ministry of Defence were randomly selected. Multiple regression analysis was used to test the relationship between independent variables and dependent variable.

Findings- It is found that leadership commitment and leadership communication influenced the efficiency of procurement staff significantly.

Conclusion- The practical implications are the discovery of theoretical, personal, and workplace practical best practices for the establishment of strategies for enhancing procurement decisions in procurement management and contract.

Keywords: Procurement decision, leadership commitment, leadership communication, defence.

JEL Codes: C61, L84, M12

\section{INTRODUCTION}

All nations allocate huge budgets for military spending to keep their army in full readiness to protect the achievements of the nation, (Bodea, et al., 2016). Therefore, military spending and inefficiency of public procurement have become a burden for many countries which depend on revenues and taxes, including oil producing countries such as Libya (D'Agostino et al., 2016). This scenario becomes critical among oil producing countries after the fall of oil price. One of the solutions is reducing military spending to save a lot of money to avoid any budget deficit, but that may effect on the performance of the troops.

One of the strategies to reduce budget deficit without compromising military performance is by reforming the procurement decisions by improving the performance of the staff. In this research, the researcher seeks to impose leadership values that could increase the efficiency of the staff of the military procurement department, namely, leadership commitment and leadership communication (Mazzei, et al., 2016; Obeidat, et al., 2016; Dey, et al., 2015).

Improving the performance of defence procurement, increasing the efficiency of employees and empowering them through good leadership values help in fighting corruption, promotes transparency and reduces prices (Vaidya \& Soar, 2017). The entire procurement plan can sometimes be achieved with a lower budget (Liebman \& Mahoney, 2017). Here comes the role of the 
government, before thinking about reducing the volume of military spending must first reform the procurement decision and raise the efficiency of defence procurement. The Ministry of Defence is able to purchase and obtain high quality products at affordable prices if it has qualified personnel. This is done by training and creating a focus on incentives such as bonuses, promotions, financial grants and good salaries.

To assist in the process of establishing effective procurement decision, this research proposes the factors of leadership commitment and leadership communication. All these values are embedded in the conceptual framework. The paper is organized as follows. Next section presents a theoretical justification for every element in the conceptual framework. Section 3 discusses research approach adopted to validate the proposed factors. Finally, a conclusion is presented in the concluding section.

\section{LITERATURE REVIEW}

For enhancing procurement decision and in turn improving procurement efficiency, this study argues that effective organizational leadership is required. The discussion on the values to develop effective organizational leadership is offered in the following sections.

\subsection{Public and Defence Procurement}

Most countries tend to cut spending to address the general budget deficit (Guajardo et al., 2014; Morrissey, 2015). Countries that are experiencing economic problems due to the decrease in oil price such as Libya and other Arab countries are not exceptional. Since military spending of all countries is always high, there are voices calling for reducing military spending and operational costs (Biscop, 2016). However, the reduction in military budget could negatively affect the readiness of the armies, and the question here is that 'how to maintain national security at lower cost'? To face this issue this study argues that the leaders in military organization should give more attention to effective procurement decision. This is to ensure that the procurement is done at lowest cost without compromising on the quality of procured items. To enhance organizational leadership and in turn procurement decision this study proposes the elements of leadership commitment and leadership communication.

\subsection{Leadership Commitment}

Leadership (top management) commitment exists when senior executives create and sustain clear values at the workplace (Hossain \& Saleh, 2016). Leadership must be consistent and reflect its commitment through an organization's philosophy, goals, policies, priorities, and executive behaviors. Any reform on public procurement and procurement decision require a strong commitment from the senior management to adopt new organizational approach and to urge staffs to commit themselves in implementing the new approach. This is because a new approach usually requires a collective commitment from the managers and employees towards the objectives that require effort, time, financial resources, training, good work environment and others (Wang et al., 2014; Choudhary, 2013; Keskes, 2014; Lam et al., 2015; Sabharwal, 2014; Garrido-Moreno et al., 2014). They found that there is a significant relationship between leadership commitment in organization and organizational performance.

On the other hand, when making changes in an organization, the first who resists the changing is employees. A big problem could occur if top management is not committed to the goals and visions of change and able to mobilize others to achieve extraordinary things in organizations. Leadership role is linked to practices used by leaders to transform values into actions and visions into reality, obstacles into innovation and division into solidarity. The leaders must be able to create an environment in which people turn difficult opportunities into great success (Ramazani \& Jergeas, 2015). Procurement and contract management need top management commitment to drive the organizations including military organization towards new goals and lead employees towards performance improvement. Thus the following hypothesis is developed:

$\mathrm{H} 1$. There is a positive relationship between leadership commitment and enhanced military procurement decision

\subsection{Leadership Communication}

A large number of organizational problems occur as a result of poor leadership communication (Jacobs et al., 2013). It is precisely this problem that underlines the need for leaders to focus on becoming great communicators. Effective communication is a key factor for professional success, whether it is at the level of interpersonal relations, between groups or within an organization. Trust is very important between leaders and employees. People will not open up to those who do not trust them. It is best to create confidence by winning it through proper communication, thinking and decision. People will 
forgive many things where there is a trust. The more personal and engaging the conversation, the more effective it is. Communication and idea should always be simple and concise better than complex and confusing, (Ladyman et al., 2013). The best contacts are not only skilled at learning and gathering information while communicating, they are also adept at conveying ideas, aligning expectations, inspiring work, and spreading their vision.

It is very important that the leadership in the military organization be able to communicate and convince subordinates to ensure the success of any reform initiative to enhance procurement decision and improve overall performance. The leaders must maximize the potential of others and motivate them to achieve common goals and be able to manage individual and group performance with an understanding of group dynamics and team building (Gilley et al., 2015). Leaders that are capable of communicating with staff always succeed in implementing reform within the organization (Gilley et al., 2015). Zohar and Polachek (2014), Dobre (2013) and Morphitou (2017) found that there is a significant relationship between leadership communication in organization and organizational performance.

If an organization decides to raise staff efficiency by adopting a new management approach such as empowering, training and motivating staff, it needs leaders that have the ability to communicate. There is no doubt that the success of these leaders in achieving the objectives of the organization leads to an increase in efficiency and organizational performance. It has been found in many studies that leaders must listen effectively and communicate effectively to convince others and build consensus and trust (Beiko et al., 2016; Hopkins et al., 2015), that is needed by procurement department. Thus the following hypothesis is developed:

H2. There is a positive relationship between leadership communication and enhanced procurement decisions.

\section{RESEARCH METHODOLOGY}

The data of this study were collected through a survey approach. Survey is considered to be the favored tool for data collection amongst quantitative researchers (Fowler, 2009). In addition, it is one of the most common methods of collecting data for studying critical success factors. This study utilized stratified random sampling as a sampling technique (Sekaran, 2003). Stratified random sampling, as its name suggests, includes the process of stratification and segregation, followed by random selection of objects from each stratum (Sekaran, 2003; Fowler, 2009; Babin \& Griffin, 2010). It allows every element in the population to have equal probability of being chosen Sekaran (2003). It also has the least bias and offers the most generalizability (Sekaran, 2003). A total of 450 employees in the Libyan Ministry of Defense were randomly selected. Multiple regression analysis was used to test the relationship between independent variables and dependent variable.

\subsection{Response Rate}

Out of 450 distributed questionnaires, 392 were returned. This resulted in a response rate of $87.11 \%$. As suggested by Sekaran (2003), a response rate of $30 \%$ is considered adequate for mail survey research. Based on this suggestion, the response rate of this study $(87.11 \%)$ was above the recommended rate. In turn, the findings of this research can be generalized to the population.

\subsection{Profile of Respondents}

The frequency and percentage of each demographic profile are illustrated in Table 1. The reported demographic profiles include education level, organization type, position, and staff criteria. Profile of respondents does not allow us to make conclusions beyond the data we have analyzed or reach conclusions regarding any hypotheses we might have made. They are simply a way to describe our data. 
Table 1: Background of the Respondents ( $N=350)$

\begin{tabular}{|c|c|c|}
\hline & Frequency & Percent (\%) \\
\hline \multicolumn{3}{|l|}{ Education Level } \\
\hline High school \& below & 22 & 6.3 \\
\hline Diploma \& bachelor degree & 227 & 64.9 \\
\hline Post degree & 101 & 28.9 \\
\hline \multicolumn{3}{|l|}{ Organization Type } \\
\hline Ministry of Defence & 217 & 62.0 \\
\hline Procurement and contract management & 95 & 27.1 \\
\hline Planning and follow-up department & 38 & 10.9 \\
\hline \multicolumn{3}{|l|}{ Position } \\
\hline Top management & 25 & 7.1 \\
\hline Middle management & 33 & 9.4 \\
\hline Supervision & 45 & 12.9 \\
\hline Controller & 48 & 13.7 \\
\hline Heads of divisions & 61 & 17.4 \\
\hline Employee & 138 & 39.4 \\
\hline \multicolumn{3}{|l|}{ Staff Criteria for } \\
\hline Experience & 168 & 48.0 \\
\hline Qualification & 97 & 27.7 \\
\hline Language & 59 & 16.9 \\
\hline All of them & 26 & 7.4 \\
\hline
\end{tabular}

Table 1 shows that the majority of the sample is diploma and bachelor degree holders (64.9\%), then post graduate degree holders (28.9\%) and finally high school and below degrees (only 6.3\%). In term of the organization type, the most of the participants are working in Ministry of Defence (62.0\%), then the participants who work in procurement and contract management (27.1\%) and then those who work in planning and follow-up department (10.9\%). On the hand, the most of the participants are working as employee (39.4\%), then head of division (17.4\%), then controller (13.7\%), then supervision (12.9\%), then middle management $(9.4 \%)$ and finally top management $(7.1 \%)$. The result also show that most of the staff criteria are for experience (48.0\%), then for qualification (27.7\%), then language $(16.9 \%)$ and all of them $(7.4 \%)$.

\subsection{Reliability Analysis}

Reliability analysis allows studying the properties of measurement scales and the items that make them up. Reliability is referred to as when a researcher's approach is consistent across different researchers and different projects and it refers to the consistency, stability and repeatability of results, whereby the result of a researcher is considered reliable if consistent results have been obtained in identical situations but different circumstances (Twycross \& Shields, 2004). The reliability of whole data measured using the Cronbach alpha analysis for each factor in the questionnaire. Table 2 shows Cronbachs' alpha values for this study factors. 
Table 2: Cronbach's Alpha Values of the Studied Factors

\begin{tabular}{|l|l|l|}
\hline No & Factor & Cronbach's Alpha \\
\hline 1 & Procurement Decisions & .839 \\
\hline 2 & Leadership & .764 \\
\hline 3 & Human Resource & .910 \\
\hline 4 & Quality & .870 \\
\hline 5 & Motivation & .837 \\
\hline \multicolumn{2}{|l|}{ Cronbach's Alpha: 0.935} & \\
\hline
\end{tabular}

Table 2 shows Cronbach's Alpha values of the studied factors. As all factors have reliability values above 0.70 and Cronbach's Alpha value of all factors is 0.935 , which is more than recommended level of 0.7 , it could be said that the measurement for items are reliable.

\subsection{Multiple Regression Analysis}

Date refinement was undertaken prior to multiple regression analysis. It was divided into data screening and data testing, which aim to fulfill the multivariate assumptions (Hair et al., 2006). Data screening consists of three tests which are missing data, response bias and outliers identification. On the other hand, data testing consists of linearity, normality, homoscedasticity and multicollinearity tests. The criteria for all these tests were met in this study.

To test this research hypotheses multiple regression analysis was utilized and its findings are illustrated in Table 3. As illustrated in Table 3, the value of adjusted $R$ square is 0.857 . This shows that all independent variables (leadership commitment and leadership communication) affect dependent variable (procurement decisions) significantly. The results indicate that the model explained 85.7 percent of the procurement decisions $\left(R^{2}=0.857, F=184.044, p<0.05\right)$.

Table 3: Effect of Independent Variables on Procurement Decisions

\begin{tabular}{llll}
\hline & B & T & Sig. \\
\hline Leadership Commitment & .056 & 2.384 & .018 \\
Leadership Communication & .059 & 2.094 & .037 \\
\hline $\mathrm{R}^{2}$ & 0.857 & & \\
$\mathrm{~F}$ & 184.044 & & \\
Sig. & 0.000 & & \\
\hline
\end{tabular}

Both variables were found to have significant effect on procurement decisions, namely, leadership commitment ( $B=0.055$, $t=2.384, p<0.05)$ and leadership communication $(B=0.059, t=2.094, p<0.05)$. In summary, the above findings show that there are significant effects of leadership commitment and leadership communication on procurement decisions. Thus hypotheses $\mathrm{H} 1 \mathrm{and}$ $\mathrm{H} 2$ were accepted.

\section{DISCUSSION}

This study found that leadership commitment and leadership communication were positively and significantly influenced on enhanced procurement decisions. This finding is consistent with the previous studies such as Wang et al. (2014), Choudhary (2013), Keskes (2014), Lam et al. (2015), Zohar and Polachek (2014) and Morphitou (2017). From this result it could be said that for improving employees' efficiency in procurement management, top management must make a great effort to focus on leadership commitment and leadership communication. The commitment of the leadership to the objectives of the organization and the ability of leadership to convince employees to accept change by good communication and build confidence with people and involve them in most of the decisions that concern the organization, will benefit and improve performance. Thus could 
increase employee's loyalty to the organization and feel them that the organization is their property, thereby increasing organizational performance.

\section{CONCLUSION}

The objective of this study was to determine whether critical success factors leadership commitment and leadership communication enhancing the procurement decisions. From the findings, the proposed conceptual framework was substantially validated. The findings showed that the effect of leadership commitment and communication on the enhanced procurement decisions were significant.

It should be noted that this study has contributed in defense procurement, but many limitation must be considered. First, the context of this research is limited to defense procurement staff. For future research it is suggested that a study be conducted of public procurement staff. Second, this conceptual framework was tested and examined by Libyan Ministry of Defense. Thus, feedback from the public sector is important.

\section{REFERENCES}

Babin, Z., Griffin, C. (2010). Business research method (8th ed.). Ohio: South-Western/Cengage Learning.

Beiko, D., Barling, J., Houle, A. M., Davies, T. O., Oake, J. S. (2016). Exploring the business of urology: leadership. Canadian Urological Association Journal, 10(7-8), 241.

Biscop, S. (2016). All or nothing? The EU global strategy and defence policy after the Brexit. Contemporary Security Policy, 37(3), 431-445.

Bodea, C., Higashijima, M., Singh, R. J. (2016). Oil and civil conflict: can public spending have a mitigation effect?. World Development, 78, 1-12.

Choudhary, A. I., Akhtar, S. A., Zaheer, A. (2013). Impact of transformational and servant leadership on organizational performance: a comparative analysis. Journal of Business Ethics, 116(2), 433-440.

d'Agostino, G., Dunne, J. P., Pieroni, L. (2016). Government spending, corruption and economic growth. World Development, 84, $190-205$.

Dey, P. K., Bhattacharya, A., Ho, W., Clegg, B. (2015). Strategic supplier performance evaluation: a case-based action research of a UK manufacturing organisation. International Journal of Production Economics, 166, 192-214.

Dobre, O. I. (2013). Employee motivation and organizational performance. Review of Applied Socio-Economic Research, 5(1), 53-60.

Fowler, F. J. Jr. (2009). Survey research method. London: Sage Publications

Garrido-Moreno, A., Lockett, N., García-Morales, V. (2014). Paving the way for CRM success: the mediating role of knowledge management and organizational commitment. Information \& Management, 51(8), 1031-1042.

Gilley, J. W., Gilley, A. M., Jackson, S. A., Lawrence, H. (2015). Managerial practices and organizational conditions that encourage employee growth and development. Performance Improvement Quarterly, 28(3), 71-93.

Guajardo, J., Leigh, D., Pescatori, A. (2014). Expansionary austerity? International evidence. Journal of the European Economic Association, 12(4), 949-968.

Hopkins, M. M., O'Neil, D. A., Stoller, J. K. (2015). Distinguishing competencies of effective physician leaders. Journal of Management Development, 34(5), 566-584.

Hossain, S., Saleh, F. (2016). Role of leadership in performance excellence. GLOBAL JOURNAL OF BUSINESS MANAGEMENT.

Jacobs, G., van Witteloostuijn, A., Christe-Zeyse, J. (2013). A theoretical framework of organizational change. Journal of Organizational Change Management, 26(5), 772-792.

Keskes, I. (2014). Relationship between leadership styles and dimensions of employee organizational commitment: a critical review and discussion of future directions. Intangible Capital, 10(1).

Ladyman, J., Lambert, J., Wiesner, K. (2013). What is a complex system?. European Journal for Philosophy of Science, 3(1), 33-67

Lam, M., O'Donnell, M., Robertson, D. (2015). Achieving employee commitment for continuous improvement initiatives. International Journal of Operations \& Production Management, 35(2), 201-215.

Liebman, J. B., Mahoney, N. (2017). Do expiring budgets lead to wasteful year-end spending? Evidence from federal procurement. American Economic Review, 107(11), 3510-49.

DOI: 10.17261/Pressacademia.2018.942 
Mazzei, M. J., Flynn, C. B., Haynie, J. J. (2016). Moving beyond initial success: promoting innovation in small businesses through highperformance work practices. Business Horizons, 59(1), 51-60.

Morphitou, R. N. (2017). Female entrepreneurs in Cyprus: characteristics, barriers, and steps for development. International Journal of Management Cases, 19(2).

Morrissey, O. (2015). Aid and government fiscal behavior: assessing recent evidence. World Development, 69, 98-105.

Obeidat, B. Y., Hashem, L., Alansari, I., Tarhini, A., Al-Salti, Z. (2016). The effect of knowledge management uses on total quality management practices: a theoretical perspective. Journal of Management and strategy, 7(4), 18.

Ramazani, J., Jergeas, G. (2015). Project managers and the journey from good to great: the benefits of investment in project management training and education. International Journal of Project Management, 33(1), 41-52.

Sabharwal, M. (2014). Is diversity management sufficient? Organizational inclusion to further performance. Public Personnel Management, 43(2), 197-217.

Sekaran, U. (2003). Research method for business: a skill building approach (4th ed.). Danvers,

MA: John Wiley \& Sons.

Twycross, A., Shields, L. (2004). Validity and reliability--what's it all about? Part 1 validity in quantitative studies: this is one of a series of short papers on aspects of research by Alison Twycross and Linda Shields. Paediatric nursing, 16(9), 28-29.

Vaidya, A. N. K., Soar, J. (2017). Application of e-government principles in anti-corruption framework. Digital Governance and E-Government Principles Applied to Public Procurement, 56.

Wang, H., Sui, Y., Luthans, F., Wang, D., Wu, Y. (2014). Impact of authentic leadership on performance: role of followers' positive psychological capital and relational processes. Journal of Organizational Behavior, 35(1), 5-21.

Zohar, D., Polachek, T. (2014). Discourse-based intervention for modifying supervisory communication as leverage for safety climate and performance improvement: a randomized field study. Journal of Applied Psychology, 99(1), 113. 